\title{
Fenologics Characteristics of the 'Siciliano' Lemon Tree on two Rootstocks Influenced by Liming and Boron Addition
}

\author{
Hélio Grassi Filho*, Antonio Roque Dechen, Elano Marçal Torquato and Carlos Henrique \\ dos Santos \\ Departamento de Recursos Naturais; Área de Ciência do Solo; Faculdade de Ciências Agronômicas - UNESP; \\ C. P. 237; 18603-970, Botucatu - SP - Brazil
}

\begin{abstract}
The current study was developed with disturbed samples of an Oxisol, in which 'Siciliano' lemon trees seedlings $(C$. limon) were grafted on sour orange tree $(C$. aurantium) and rangpur lime tree $(C$. limonia). The experiment consisted of three basis saturation levels (50, 70 and 90 percent) and three boron doses (0.5; 1.5 and $\left.4.5 \mathrm{mg} \mathrm{dm}^{-3}\right)$ in the planting with $3 \times 3 \times 2$ factorial experimental design with four replications. Mineral composition of the "Siciliano" lemon leaves as well as root system development in sour orange tree were higher than the rangpur lime tree. There was no effect in the interaction basis saturarion level and the boron doses for any of the evaluated parameters.
\end{abstract}

Key words: Liming, boron, calcium, Siciliano lemon trees, rootstocks

\section{INTRODUCTION}

The citriculture in São Paulo State has been moved from a region of high fertility soil to another region of less rich soils, looking at with frequency orchards planted in soils originally covered with savannah vegetation. As a result, it has been observed that the majority of the orchards in São Paulo State can be localized in other acidity soils. A litlle number of studies with lemon have been accomplished in Brazil. Hiroce et al. (1986), studied the influence of sixteen different rootstocks in the mineral composition of lemon trees "Siciliano" leaves in an Oxisol of Ribeirão Preto region and among the rootstocks. The major increase was observed in the boron level with the lemon trees 'Milan', which presented concentration two times bigger than the sour orange. It can be added that the annual variation in the contents of leaves nutrients received more emphasis than among the rootstocks; there was not significative correspondence among the contents of leaves nutrients and the lemon's yield.

In studies involving roots, Bohm, (1979) observed that the two principal fields of study of roots were the ecology and the physiology of the roots, which differ in finality. The study of roots ecology aimed to investigate the influence of the environmental factor over the development of the plant root system. Although the study of the roots physiology is responsible for the roots physiologic process, the occurrence of separation between the two concepts is not necessary on account of the fact that the development of the roots is ruled by internal and external factors. The study of Citrus in Brazil, (Montenegro, 1960) used the auger method, which studied the distribution of radicular system of 'Hamlin', 'Baianinha' and 'Pera' orange trees, grafting at diverse rootstocks on condition in São Paulo State. A striking influence of variety crown

\footnotetext{
* Author for correspondence
} 
above the radicular system was noted. In the horizontal distribution of roots was metted from $75 \%$ to $94 \%$ of rootlet in a medium ray of 2 meters from the trunk. In the profundity, it was observed that for trees with age of 10 years, $90 \%$ of the roots were on soil layer from surface to $60 \mathrm{~cm}$. For tree with 23 years of age, $90 \%$ of the roots reached until $90 \mathrm{~cm}$. The author observed that the soil showed influence at the rootlet (radicels) weight and the distribution of the radicular system.

Aso, (1974) studied the behavior of five rootstocks in vase with soil with addition of $\mathrm{CaCO}_{3}(1.0,2.5$, 5.0, 10.0 and $15.0 \mathrm{t} \mathrm{ha}^{-1}$ ) and observed 6 months later that the deficiency of iron presented differently among the rootstocks, such as the sour orange rootstocks showed more tolerant deficiency following Rugoso and Rangpur lime rootstocks, 'Cleopatra' tangor and Trifoliata. Rodrigues et al., (1978) studied in São Paulo State the root system of three citrus rootstocks since the age of 3 months until 36 months, originally looking at more roots in 'Rangpur' lime and afterwards continuing with the sweet orange and Trifoliata. There was change during the period studied, in the end with the sweet orange with the greater roots weight, followed by the 'Rangpur' lime and Trifoliata rootstocks. Furthermore, the work showed greater quantity of roots on the superficial layer of the soil; in the layer $0-10 \mathrm{~cm}$ there were $41 \%, 33 \%$ and $28 \%$ of the roots, corresponding respectively to Trifoliata, 'Rangpur' lime and Sweet orange, until $50 \mathrm{~cm}$ of profundity, there were $91 \%$ of Trifoliata roots, $81 \%$ of Sweet orange and $79 \%$ of 'Rangpur' lime.

Grassi Filho, (1991) studying the effect of calcium and boron in the development of root system and in the mineral composition of 'Rangpur' lime trees under controlled condition, observed that $200 \mathrm{mg}$ $\mathrm{dm}^{-3}$ dose of calcium in solution raised the weight of dry matter of the roots, stem and leaves, so that increasing the roots length, stem diameter, and leaves area and number, as well as incrementing the backlog of every nutrient in roots, stem, leaves and boron in $0.5 \mathrm{mg} \mathrm{dm}^{-3}$ dose in nutrient solution promoted the greater root length, there was not significative effect for the interaction calcium $\mathrm{x}$ boron. Boaretto et al., (1991) studied the effect of the gypsum application and liming in the soil chemical characteristics, level of leaves and productivity of 'Siciliano' lemon trees, scion at 'Rangpur' lime rootstocks in Botucatu region and observed that the gypsum dose effect over the saturation of $\mathrm{Al}$ and the levels of exchangeable $\mathrm{Ca}$ on soil was not looking at the liming dose. The gypsum dose has raised the level of $\mathrm{Ca}$ and $\mathrm{S}$ in leaves and presented a negative effect over the $\mathrm{Mg}$. In the yield there was not effect in liming and gypsum dose in total weight of fruit by plant in the first crop of 'Siciliano' lemon. Quaggio et al., (1992) studied the effect of Mg on fruit yield and the quality of 'Valência' sweet orange, on Rangpur lime and observed that dolomitic limestone was a good source of $\mathrm{Mg}$ for orange trees. Maximum yield was attained in plots with exchangeable $\mathrm{Mg}$ in soil and leaf were respectively superior to $9.0 \mathrm{mmol}_{\mathrm{c}} \mathrm{dm}^{-3}$ and the leaves level higher than $3.5 \mathrm{~g} \mathrm{~kg}^{-1}$. The addition of dolomitic liming raised linearly the contents of total soluble solids and acids on fruits, in the same pattern of the leaf $\mathrm{Mg}$ contents. Leaf analysis and soil test were effective tools to predict $\mathrm{Mg}$ availability in soil. More accurate soil testing results were obtained when samples were taken both from dripline and midrow.

The present study aimed to evaluate fenologic characteristics of the 'Siciliano' lemon tree on two rootstocks influenced by liming and boron addition.

\section{MATERIALS AND METHODS}

An Oxisol sampled at Lageado Experimental Farm was used in this work. Chemical analysis was carried out according to Raij and Quaggio, (1983), and the results are shown in Table 1 . Scion with age of 12 months were used on 'Siciliano' lemon trees (Citrus limon, B.), on two rootstocks, 'Sour' orange (Citrus aurantium, L.) and 'Rangpur' lime (Citrus limonia, L.).

The experiment consisted of three saturation levels (50, 70 and $90 \%)$, three boron levels $(0.5 ; 1.5$ and $4.5 \mathrm{mg} \mathrm{dm}^{-3}$ ) and two rootstocks, with $3 \times 3 \times 2$ factorial experimental design, with four replications, in pots with 250 of soil capacity (Gomes, 1981). Each replication was constituted by one plant.

The liming was done in first $20 \mathrm{~cm}$ of soil of pot using a limestone dolomitic with $26.9 \% \mathrm{CaO}$ and $19.8 \% \mathrm{MgO}, 45$ days before transplant. New soil analysis was achieved before transplant (Raij and Quaggio, 1983) with the purpose of verifying if the base saturation level was correct. The results of analysis are show in Table 2. In every pots, quantity of 9.3 and $855 \mathrm{mg}$ boric acid corresponding respectively to $0.5 ; 1.5$ and $4.5 \mathrm{mg}$ $\mathrm{dm}^{-3}$ boron level was added. The complete fertilization was realized with 5 liters of corral 
manure, $80 \mathrm{~g}$ of $\mathrm{P}_{2} \mathrm{O}_{5}, 20 \mathrm{~g}$ of $\mathrm{K}_{2} \mathrm{O}$ and $2 \mathrm{~g}$ of zinc. The covering fertilization was $80 \mathrm{~g}$ of $\mathrm{N}$ and $20 \mathrm{~g}$ of $\mathrm{K}_{2} \mathrm{O}$, divided in four applications (Malavolta and Violante Netto, 1989). The 'Siciliano' lemon tree leaves were sampled in the first at the experiment's begining (March of 1992), at begining of the spring (September of 1992) and in March of 1993. Forty mature leaves of each plant were sampled (Malavolta and Violante Netto, 1989) and analysed based on methodology described by Malavolta et al., (1989). The roots were sampled with auger, in March of 1992, in three samples per pot, with $10 \mathrm{~cm}$ depth and $25 \mathrm{~cm}$ distant from the trunk, packed in plastic bag. The samples were packed inside in a freezer at $2{ }^{\circ} \mathrm{C}$ and when it was analysed the roots was separated by a sieve with mesh of $1 \mathrm{~mm}$. After it was conservated inside a bottle containing preservative solution (Grassi Filho, 1995). Fresh weight, dry roots matter and roots length (Tennant, 1975), radicular surface, medium ray (Schenk and Barber, 1979) and radicular density (Zanette and Comem, 1992) were determined.

Table 1 - Chemical analysis of the Oxisol.

\begin{tabular}{|c|c|c|c|c|c|c|c|c|c|c|c|c|c|}
\hline pH & M.O. & $\mathbf{P}_{\text {resine }}$ & $\mathbf{H}^{+}+\mathbf{A l}^{+3}$ & $\mathbf{K}^{+}$ & $\mathbf{C a}^{+2}$ & $\mathrm{Mg}^{+2}$ & SB & CTC & $\mathbf{V}$ & B & $\mathbf{C u}$ & Mn & $\mathbf{Z n}$ \\
\hline $\mathrm{CaCl}_{2}$ & $\mathrm{~g} \mathrm{dm}^{-3}$ & $\mathrm{mg} \mathrm{dm}^{-3}$ & & $\cdots$ & --mmo & $\mathrm{dm}^{-3}$ & $\cdots$ & -.-- & $\%$ & - & --mg & $\mathrm{m}^{-3}$ & - \\
\hline 4.1 & 29.0 & 3.0 & 64.0 & 0.6 & 2.0 & 1.0 & 3.6 & 67.8 & 5.3 & 0.14 & 0.4 & 1.9 & 0.1 \\
\hline
\end{tabular}

Table 2 - Chemical analysis of the Oxisol after 45 days of liming.

\begin{tabular}{|c|c|c|c|c|c|c|c|c|c|c|}
\hline $\begin{array}{c}\text { Level } \\
\text { V\% } \\
\end{array}$ & $\begin{array}{c}\mathrm{pH} \\
\mathrm{CaCl}_{2}\end{array}$ & $\begin{array}{l}\text { M.O. } \\
\mathrm{g} \mathrm{dm}^{-3}\end{array}$ & $\begin{array}{c}P_{\text {resine }} \\
\mathrm{mg} \mathrm{dm}^{-3}\end{array}$ & $\begin{array}{l}\mathrm{V} \\
\% \\
\end{array}$ & $\begin{array}{c}\mathbf{H}^{+}+\mathbf{A l}^{+3} \\
-\end{array}$ & $\mathbf{K}^{+}$ & $\begin{array}{c}\mathrm{Ca}^{+2} \\
-\mathbf{m m} \\
\end{array}$ & $\begin{array}{c}\mathrm{Mg}^{+2} \\
\mathrm{dm}^{-3}-.-\end{array}$ & $\begin{array}{l}\text { SB } \\
-\end{array}$ & $\begin{array}{c}\text { CTC } \\
--\end{array}$ \\
\hline 50 & 5.4 & 29.0 & 6.0 & 54 & 37.3 & 1.2 & 26.8 & 15.7 & 43.7 & 81.0 \\
\hline 70 & 6.0 & 31.0 & 6.0 & 72 & 28.8 & 1.4 & 45.9 & 26.9 & 74.2 & 103.0 \\
\hline 90 & 6.3 & 33.0 & 7.0 & 87 & 16.5 & 1.6 & 67.5 & 41.4 & 110.5 & 127.0 \\
\hline
\end{tabular}

\section{RESULTS AND DISCUSSION}

\section{Chemical Analysis of the Leaves}

In the first sampling (Table 3), it has been observed that the plant showed low levels of $\mathrm{N}$, $\mathrm{Ca}, \mathrm{Zn}$ and $\mathrm{Mn}$, the level of nutrients was considered adequate according to GPACC (Grupo Paulista de Adubação e Calagem para Citros, 1994). $\mathrm{Zn}$ and $\mathrm{Mn}$ were supplied with the application of $\mathrm{ZnSO}_{4}$ to the $0.5 \%, \mathrm{MnSO}_{4}$ to the $0.3 \%$ and urea to the $0.5 \%$ in the leaves. In Table 3 is presented the difference between the rootstocks, with the 'Sour' orange showing higher values for the N, Mg and $\mathrm{Zn}$ in 'Siciliano' lemon tree leaves, and Rangpur lime, only the $\mathrm{Mn}$; there were not differences between the rootstocks.

The base saturation levels promoted differences on the $\mathrm{K}$ levels of the leaves, and the $70 \%$ level of base saturation showed the higher levels followed by $90 \%$ and $50 \%$ levels. It was also observed that the $\mathrm{B}$ doses in the soil raised levels of the element on leaves, however the $\mathrm{B}$ dose of $4.5 \mathrm{mg} \mathrm{dm}^{-3}$ promoted higher leaves level in comparison to the levels proposed by GPACC (1994). The B dose of $1.5 \mathrm{mg} \mathrm{dm}^{-3}$ promoted adequate levels for leaves, while the $\mathrm{B}$ dose of $0.5 \mathrm{mg} \mathrm{dm}^{-3}$ promoted levels lower than the proposed by Violante Netto et al., (1988). The B doses applied in soil showed, directly on leaf level according to the order of values $4.5>1.5>0.5 \mathrm{mg} \mathrm{dm}^{-3}$. Boron doses were injurious to burn leaves, sprout and apical branch 30 days after transplant when boron levels in the leaves ranged from 600 to $850 \mathrm{mg} \mathrm{Kg}^{-1}$.

In the second sampling of the leaves, in September of 1992, observed in Table 4, there was raise on the $\mathrm{N}$ and $\mathrm{K}$ levels whereas the Ca levels showed low. In the base saturation levels it was observed differences only to $\mathrm{Mg}$; the greater level was obtained with $90 \%$ base saturation, followed by $50 \%$ and $70 \%$ base saturation, confirmed that the liming with dolomitcs limestone was sufficient to raise the level of $\mathrm{Mg}$ in leaves, according to Quaggio, (1992).

Regarding the $\mathrm{B}$ doses, there were answers for the nutrients $\mathrm{P}, \mathrm{K}, \mathrm{Ca}, \mathrm{Mg}$ and $\mathrm{Mn}$. The $\mathrm{B}$ dose of 4.5 $\mathrm{mg} \mathrm{dm}$ promoted higher levels on leaves of $\mathrm{P}, \mathrm{K}$ and $\mathrm{B}$, followed by 1.5 and $0.5 \mathrm{mg} \mathrm{dm}^{-3}$ of $\mathrm{B}$. About the nutrients $\mathrm{Ca}, \mathrm{Mg}$ and $\mathrm{Mn}$, there was an inverse result. The doses 4.5 and $1.5 \mathrm{mg} \mathrm{dm}^{-3}$ promoted excessive values on the leaves and the $0.5 \mathrm{mg} \mathrm{dm}^{-3}$ dose promoted adequate levels; there were differences among the treatment of B dose.

Among the rootstocks, the 'Rangpur' lime presented N, $\mathrm{Mg}$ and $\mathrm{Zn}$ levels higher and for the 'Sour' orange, the $\mathrm{Mn}$ was superior. For the other element there were differences among the rootstocks. 
Table 3 - Nutrients medium levels in leaves of 'Siciliano' lemon trees, 15 days after the installation of test.

\begin{tabular}{|c|c|c|c|c|c|c|c|c|}
\hline \multirow{2}{*}{ Treatments } & \multicolumn{5}{|c|}{ Macronutrients ( $\mathrm{g} \mathrm{Kg}^{-1}$ ) } & \multicolumn{3}{|c|}{ Micronutrients (mg Kg ${ }^{-1}$ ) } \\
\hline & $\mathbf{N}$ & $\mathbf{P}$ & $\mathbf{K}$ & $\mathbf{C a}$ & Mg & B & Mn & $\mathbf{Z n}$ \\
\hline \multicolumn{9}{|c|}{ Base Saturation Level (V\%) $)^{\#}$} \\
\hline 50 & 15.8 & 1.2 & $13.0 \mathrm{~b}$ & 20.7 & 3.5 & 84.1 & 23.8 & 20.5 \\
\hline 70 & 17.5 & 1.2 & $14.5 \mathrm{a}$ & 19.7 & 3.6 & 88.5 & 22.1 & 20.2 \\
\hline 90 & 17.0 & 1.2 & $13.7 \mathrm{ab}$ & 21.9 & 3.6 & 77.3 & 28.3 & 22.0 \\
\hline Test $\mathrm{F}$ & ns & $\mathrm{ns}$ & * & $\mathrm{ns}$ & $\mathrm{ns}$ & $\mathrm{ns}$ & $\mathrm{ns}$ & ns \\
\hline \multicolumn{9}{|c|}{ Boron $\left.(\mathbf{m g ~ d m})^{-3}\right)^{\#}$} \\
\hline 0.5 & 17.5 & 1.2 & 13.6 & 20.0 & 3.6 & $34.9 \mathrm{c}$ & 25.5 & 21.3 \\
\hline 1.5 & 16.8 & 1.2 & 13.5 & 21.2 & 3.5 & $64.7 \mathrm{~b}$ & 24.9 & 21.4 \\
\hline 4.5 & 16.2 & 1.2 & 14.2 & 21.0 & 3.5 & $150.2 \mathrm{a}$ & 23.8 & 19.9 \\
\hline Test $\mathrm{F}$ & ns & $\mathrm{ns}$ & ns & ns & ns & $\mathrm{ns}$ & ns & ns \\
\hline \multicolumn{9}{|c|}{ Rootstocks } \\
\hline Rangpur lime & $16.1 \mathrm{~b}$ & 1.2 & 13.7 & 20.4 & $3.0 \mathrm{~b}$ & 80.6 & 32.4 & 19.9 \\
\hline Sour orange & $17.5 \mathrm{a}$ & 1.2 & 13.8 & 21.1 & $4.2 \mathrm{a}$ & 86.0 & 17.1 & 21.8 \\
\hline Test $\mathrm{F}$ & * & $\mathrm{ns}$ & $\mathrm{ns}$ & ns & * & $\mathrm{ns}$ & * & * \\
\hline Medium & 16.8 & 1.2 & 13.8 & 20.8 & 3.6 & 83.3 & 24.8 & 20.9 \\
\hline CV\% & 14.9 & 12.6 & 14.4 & 18.5 & 17.4 & 18.7 & 16.4 & 16.6 \\
\hline
\end{tabular}

\# Same letters don't have differencce significative (5\% probability - Tukey test).

Table 4 - Nutrients medium levels in leaves of 'Siciliano' lemon trees, 6 months after the installation of test.

\begin{tabular}{|c|c|c|c|c|c|c|c|c|}
\hline \multirow{2}{*}{ Treatments } & \multicolumn{5}{|c|}{ Macronutrients $\left(\mathrm{g} \mathrm{Kg}^{-1}\right)$} & \multicolumn{3}{|c|}{ Micronutrients (mg Kg ${ }^{-1}$ ) } \\
\hline & $\mathbf{N}$ & $\mathbf{P}$ & $\mathbf{K}$ & Ca & Mg & B & Mn & Zn \\
\hline \multicolumn{9}{|c|}{ Base Saturation Level $(\mathrm{V} \%)^{\#}$} \\
\hline 50 & 47.0 & 1.8 & 20.1 & 24.5 & $3.3 \mathrm{ab}$ & 228.7 & 77.8 & 63.1 \\
\hline 70 & 46.4 & 1.7 & 19.4 & 24.5 & 31.b & 228.1 & 86.8 & 59.6 \\
\hline 90 & 48.0 & 1.7 & 21.5 & 25.5 & $3.7 \mathrm{a}$ & 289.5 & 83.2 & 60.1 \\
\hline Test F & $\mathrm{ns}$ & ns & ns & $\mathrm{ns}$ & $*$ & ns & ns & ns \\
\hline \multicolumn{9}{|c|}{ Boron $\left(\mathrm{mg} \mathrm{dm}^{-3}\right)^{\#}$} \\
\hline 0.5 & 46.0 & $1.6 \mathrm{~b}$ & $17.2 \mathrm{~b}$ & $26.9 \mathrm{a}$ & $3.5 \mathrm{a}$ & $80.7 \mathrm{c}$ & $88.0 \mathrm{a}$ & 66.3 \\
\hline 1.5 & 48.4 & $1.6 \mathrm{~b}$ & $19.3 \mathrm{ab}$ & $26.4 \mathrm{a}$ & $3.6 \mathrm{a}$ & $276.4 \mathrm{~b}$ & $94.9 \mathrm{a}$ & 62.9 \\
\hline 4.5 & 46.9 & $1.8 \mathrm{a}$ & $24.6 \mathrm{a}$ & $21.3 \mathrm{~b}$ & $3.0 \mathrm{~b}$ & $389.1 \mathrm{a}$ & $64.9 \mathrm{~b}$ & 53.6 \\
\hline Test F & $\mathrm{ns}$ & $*$ & $*$ & $*$ & $\mathrm{~ns}$ & $*$ & * & $\mathrm{ns}$ \\
\hline \multicolumn{9}{|c|}{ Rootstocks $^{\#}$} \\
\hline Rangpur lime & $49.6 \mathrm{a}$ & 1.6 & 21.5 & 24.5 & $3.7 \mathrm{a}$ & 260.9 & $72.8 \mathrm{~b}$ & $62.1 \mathrm{a}$ \\
\hline Sour orange & $45.6 \mathrm{~b}$ & 1.8 & 21.0 & 25.1 & $3.0 \mathrm{~b}$ & 236.6 & $92.5 \mathrm{a}$ & $60.0 \mathrm{~b}$ \\
\hline Test F & $*$ & ns & $\mathrm{ns}$ & ns & $*$ & ns & $*$ & $*$ \\
\hline Medium & 47.6 & 1.7 & 21.3 & 24.8 & 3.4 & 248.7 & 82.6 & 61.1 \\
\hline $\mathrm{CV} \%$ & 6.8 & 10.6 & 11.7 & 9.7 & 10.4 & 22.8 & 19.6 & 21.0 \\
\hline
\end{tabular}

\# Same letters don't have differencce significative (5\% probability - Tukey test).

In the 12 months after the installation of the test new sampling of leaf was analysed and the results (Table 5) showed that there was reduction on medium levels of all nutrients analysed. The levels of $\mathrm{Ca}$ found out presented low and other nutrients in adequate levels. The levels encountered were lower than the level obtained in second samples
(Table 4) due to physiological distribution promoted by plants development.

At the base saturation levels it has been observed that $\mathrm{Ca}$ and $\mathrm{Mg}$ presented differences among the treatments when the $90 \%$ base saturation promoted higher levels followed by $70 \%$ and $50 \%$ alike the results obtained by Quaggio, (1992). 
Table 5 - Nutrients medium levels in leaves of 'Siciliano' lemon trees, 12 months after the installation of test.

\begin{tabular}{|c|c|c|c|c|c|c|c|c|}
\hline \multirow{2}{*}{ Treatments } & \multicolumn{5}{|c|}{ Macronutrients $\left(\mathrm{g} \mathrm{Kg}^{-1}\right)$} & \multicolumn{3}{|c|}{ Micronutrients (mg Ka ${ }^{-1}$ ) } \\
\hline & $\mathbf{N}$ & $\mathbf{P}$ & $\mathbf{K}$ & Ca & Mg & B & Mn & Zn \\
\hline \multicolumn{9}{|c|}{ Base Saturation Level $(\mathrm{V} \%)^{\#}$} \\
\hline 50 & 31.7 & 1.3 & 17.1 & $15.1 \mathrm{~b}$ & $3.5 \mathrm{~b}$ & 52.5 & 39.3 & 34.0 \\
\hline 70 & 30.6 & 1.3 & 16.0 & $16.3 \mathrm{~b}$ & $3.5 \mathrm{~b}$ & 56.2 & 44.0 & 35.3 \\
\hline 90 & 31.0 & 1.4 & 15.9 & $19.1 \mathrm{a}$ & $3.8 \mathrm{a}$ & 57.8 & 44.6 & 33.7 \\
\hline Test F & ns & $\mathrm{ns}$ & ns & $*$ & $*$ & $\mathrm{~ns}$ & $\mathrm{~ns}$ & $\mathrm{~ns}$ \\
\hline \multicolumn{9}{|c|}{ Boron $\left(\mathrm{mg} \mathrm{dm}^{-3}\right)^{\#}$} \\
\hline 0.5 & 31.0 & 1.3 & $16.0 \mathrm{ab}$ & 16.1 & 3.6 & $35.0 \mathrm{c}$ & 40.1 & $30.7 \mathrm{~b}$ \\
\hline 1.5 & 31.5 & 1.4 & $15.8 \mathrm{~b}$ & 17.0 & 3.7 & $50.3 \mathrm{~b}$ & 44.3 & $33.8 \mathrm{~b}$ \\
\hline 4.5 & 30.8 & 1.4 & $17.2 \mathrm{a}$ & 17.3 & 3.6 & $81.2 \mathrm{a}$ & 43.5 & $38.4 \mathrm{a}$ \\
\hline Test F & ns & ns & $*$ & $\mathrm{~ns}$ & ns & $*$ & $*$ & $*$ \\
\hline \multicolumn{9}{|c|}{ Rootstocks $^{\#}$} \\
\hline Rangpur lime & $32.3 \mathrm{a}$ & $1.4 \mathrm{a}$ & $15.8 \mathrm{~b}$ & $17.9 \mathrm{a}$ & $4.0 \mathrm{a}$ & 56.1 & 41.8 & $32.4 \mathrm{~b}$ \\
\hline Sour orange & $29.9 \mathrm{~b}$ & $1.3 \mathrm{~b}$ & $16.9 \mathrm{a}$ & $15.8 \mathrm{~b}$ & $3.3 \mathrm{~b}$ & 55.5 & 43.5 & $36.2 \mathrm{a}$ \\
\hline Test F & $*$ & $*$ & $*$ & $*$ & $*$ & $\mathrm{~ns}$ & ns & $*$ \\
\hline Medium & 31.1 & 1.4 & 16.4 & 16.8 & 3.6 & 55.8 & 42.6 & 34.3 \\
\hline $\mathrm{CV} \%$ & 4.8 & 5.8 & 5.8 & 7.6 & 5.5 & 13.8 & 10.0 & 9.4 \\
\hline
\end{tabular}

\# Same letters don't have differencce significative (5\% probability - Tukey test).

The $\mathrm{K}$ and $\mathrm{Zn}$ nutrients presented differences among levels in the leaves promoted by B doses in the soil and the higher level has been obtained in $4.5 \mathrm{mg} \mathrm{dm}^{-3}$ treatment, followed by 1.5 and $0.5 \mathrm{mg}$ $\mathrm{dm}^{-3}$ treatment. These results demonstrate minor plant development due to toxic effect of $4.5 \mathrm{mg}$ $\mathrm{dm}^{-3}$ dose.

Regarding the rootstocks the Rangpur lime showed higher levels for $\mathrm{N}, \mathrm{P}, \mathrm{Ca}$ and $\mathrm{Mg}$ whereas that for the 'Sour' orange presented higher levels for $\mathrm{K}$ and $\mathrm{Zn}$.

\section{Valuation of the radicular system}

The results of the treatment studied showed that there was answer for the three base saturation levels and boron doses in soil. For the rootstocks it was observed that there were not differences for the radicular surface showing significance for length, density and medium ray of roots.

In Table 6, it is presented the results of fresh and dry weight of root, increasing significantly with the increment of base saturation levels in function of increased level of calcium in soil as Grassi Filho, (1991), Marschner, (1986), Mangel and Kirkby, (1987) and Malavolta et al., (1989). About the B levels on soil, it was observed with the elevation of the $\mathrm{B}$ dose that there were minor yield of fresh and dry weight of root, there were not differences between 0.5 and $1.5 \mathrm{mg} \mathrm{dm}^{-3} \mathrm{~B}$ doses, being these upper values obtained with $4.5 \mathrm{mg} \mathrm{dm}^{-3}$.
About the rootstocks, there were not differences for the radicular system weight. There were differences among the values of base saturation levels to the rootstocks 'Sour' orange and to 'Rangpur' lime, the $70 \%$ dose saturation promoted the greater value at the weight fre sh matter.

The results of roots length (Table 6) showed that there were base saturation level effects, boron doses and differences among the rootstocks.

About the base saturation levels, the value obtained with $90 \%$ was different from the $70 \%$ and $50 \%$ levels, with the elevation of the calcium levels in soil and with the decrease of aluminium levels the radicular system has a major development, according to Grassi Filho, (1991).

About the boron doses of 0.5 and $1.5 \mathrm{mg} \mathrm{dm}^{-3}$ in the soil, there were differences; however showed higher when compared to results provided by $4.5 \mathrm{mg} \mathrm{dm}^{-3}$ dose. These results agreed with the excessive effects of B in soil, affecting the length radicular system development. About the rootstocks, the 'Sour' orange root length presented upper to 'Rangpur' lime.

About the boron dose of $4.5 \mathrm{mg} \mathrm{dm}^{-3}$, it was promoted the lower value of roots density due to toxic effect in radicular system development, there were not differences between 0.5 and $1.5 \mathrm{mg} \mathrm{dm}^{-3}$ doses. 
Table 6 - Fresh and dry weight root $(\mathrm{g})$, lenght $(\mathrm{cm})$, density $\left(\mathrm{cm} \mathrm{cm}^{-3}\right)$, medium ray $(\mathrm{mm})$ and radicular surface $\left(\mathrm{cm}^{2}\right)$ of two rootstocks of "Siciliano" lemon tree, 12 months after the installation of test.

\begin{tabular}{|c|c|c|c|c|c|c|}
\hline \multirow[b]{2}{*}{ Treatments } & \multicolumn{2}{|c|}{ Roots Weight } & \multirow{2}{*}{$\begin{array}{c}\text { Lenght } \\
\text { (cm) }\end{array}$} & \multicolumn{3}{|c|}{ Root parameters } \\
\hline & Fresh $(g)$ & Dry (g) & & $\begin{array}{c}\text { Density } \\
\left(\mathrm{cm} \mathrm{cm}^{-3}\right)\end{array}$ & $\begin{array}{c}\text { Medium } \\
\text { Ray }(\mathbf{m m})\end{array}$ & $\begin{array}{c}\text { Surface } \\
\left(\mathbf{c m}^{2}\right)\end{array}$ \\
\hline \multicolumn{7}{|c|}{ Base Saturation Level $(\mathrm{V} \%)^{\#}$} \\
\hline 50 & $0.92 \mathrm{~b}$ & $0.33 \mathrm{~b}$ & $575.3 \mathrm{~b}$ & $1.92 \mathrm{~b}$ & $0.40 \mathrm{ab}$ & $4.66 \mathrm{~b}$ \\
\hline 70 & $1.09 \mathrm{ab}$ & $0.40 \mathrm{ab}$ & $808.3 \mathrm{~b}$ & $2.12 \mathrm{~b}$ & $0.41 \mathrm{a}$ & $5.34 \mathrm{ab}$ \\
\hline 90 & $1.15 \mathrm{a}$ & $0.49 \mathrm{a}$ & $1100.3 \mathrm{a}$ & $2.88 \mathrm{a}$ & $0.37 \mathrm{~b}$ & $3.36 \mathrm{a}$ \\
\hline Test F & $*$ & $*$ & $*$ & $*$ & $*$ & $*$ \\
\hline \multicolumn{7}{|c|}{ Boron $\left(\mathrm{mg} \mathrm{dm}^{-3}\right)^{\#}$} \\
\hline 50 & $1.14 \mathrm{a}$ & $0.45 \mathrm{a}$ & $993.6 \mathrm{a}$ & $2.60 \mathrm{a}$ & $0.38 \mathrm{~b}$ & $6.03 \mathrm{a}$ \\
\hline 70 & $1.15 \mathrm{a}$ & $0.45 \mathrm{a}$ & $993.0 \mathrm{a}$ & $2.60 \mathrm{a}$ & $0.39 \mathrm{ab}$ & $6.06 \mathrm{a}$ \\
\hline 90 & $0.87 \mathrm{~b}$ & $0.31 \mathrm{~b}$ & $654.2 \mathrm{~b}$ & $1.71 \mathrm{~b}$ & $0.41 \mathrm{a}$ & $4.26 \mathrm{~b}$ \\
\hline Test F & $*$ & * & $*$ & $*$ & $*$ & $*$ \\
\hline \multicolumn{7}{|c|}{ Rootstocks $^{\#}$} \\
\hline Rangpur lime & 1.05 & 0.39 & $631.6 \mathrm{~b}$ & $2.11 \mathrm{~b}$ & $0.41 \mathrm{a}$ & 5.68 \\
\hline Sour orange & 1.05 & 0.42 & $751.7 \mathrm{a}$ & $2.51 \mathrm{a}$ & $0.38 \mathrm{~b}$ & 5.22 \\
\hline Test F & ns & ns & $*$ & $*$ & $*$ & ns \\
\hline Medium & 1.05 & 0.40 & 691.6 & 2.31 & 0.39 & 5.45 \\
\hline $\mathrm{CV} \%$ & 29.3 & 39.9 & 31.9 & 31.9 & 12.7 & 27.8 \\
\hline
\end{tabular}

\# Same letters don't have difference significative (5\% probability - Tukey test).

Regarding the rootstocks it has been realized that 'Sour' orange presented greater roots density in comparison to 'Rangpur' lime making it possible to say that this greater roots density will ensure in the field a greater potential for water and nutrients absorption (Marschner, 1986).

The medium ray value was inverse to that obtained for length, density and radicular surface, since the raise in calcium level in soil occasionated an increase in the total length of the radicular system that promoted the decrease of medium ray in function of basis saturation level increase. The inverse ocurred with boron; on account of the fact that thare was a rise in boron dose on soil there was a rise in the medium ray of radicular system; this result ocurred because of boron excess in soil. 'Rangpur' lime rootstock showed higher medium ray in comparison to 'Sour' orange.

About the radicular surface, the $90 \%$ basis saturarion levels promoted better result following $70 \%$ and $50 \%$ levels. About boron doses, there were not differences between 0.5 and $1.5 \mathrm{mg} \mathrm{dm}^{-3}$ doses; nevertheless, it was superior to $4.5 \mathrm{mg} \mathrm{dm}^{-3}$ dose. About the rootstocks there were not differences for parameter radicular surface.

The $90 \%$ basis saturation levels followed by $70 \%$ and $50 \%$ promoted increment in fresh and dry matter weight, length, density and radicular surface roots of the rootstock of 'Siciliano' lemon trees, and decrease of medium ray. The boron 4.5 $\mathrm{mg} \mathrm{dm}{ }^{-3}$ doses followed by 1.5 and $0.5 \mathrm{mg} \mathrm{dm}^{-3}$ promoted decrease in fresh and dry matter weight, length, density and radicular surface roots of the rootstocks of 'Siciliano' lemon trees, and increase of medium ray.

The basis saturation levels affected the potassium level on leaves in the first sampling, magnesium in the second and calcium and magnesium in the third sampling.

The boron levels promoted increase of phosphorus and potassium levels in leaves in the first sampling, decrease of calcium, magnesium and menganese in the second and increase of the potassium and zinc in the third sampling, due to a minor development promoted by $4.5 \mathrm{mg} \mathrm{dm}^{-3}$ boron dose in soil.

The $4.5 \mathrm{mg} \mathrm{dm}^{-3}$ boron dose was prejudicial to 'Siciliano' lemon tree development, occasioning burn leaves, sprout and apical branch 30 days after transplant when boron levels in the leaves ranged from 600 to $850 \mathrm{mg} \mathrm{kg}^{-1}$.

The $70 \%$ base saturation levels showed more appropriate for the 'Siciliano' lemon trees development than the $50 \%$ and $90 \%$ levels.

The $0.5 \mathrm{mg} \mathrm{kg}^{-1}$ boron levels dose in soil have promoted adequate levels in the leaves of 'Siciliano' lemon trees whereas the $1.5 \mathrm{mg} \mathrm{dm}^{-3}$ was high and $4.5 \mathrm{mg} \mathrm{dm}^{-3}$ was excessive.

There was different behavior among rootstocks in relation to mineral composition of the 'Siciliano' lemon leaves, as well as root system development 
and Sour orange tree higher than Rangpur lime rootstocks.

At the performance of liming, transplant, formation, fertilization, production and fertilization for citrus orchards it is necessary the chemical analyses of soil, with emphasis to micronutrients, especially in transplant.

\section{RESUMO}

O presente estudo foi desenvolvido na UNESP/Botucatu, São Paulo, Brasil, num solo identificado como Oxisol, onde foram plantadas mudas de limoeiro 'Siciliano' (C. limon) enxertadas em laranjeira 'Azeda' $(C$. aurantium) e em limoeiro 'Cravo' (C. limonia). O experimento consistiu em três níveis de saturação por bases $(50 \%, 70 \%$ e $90 \%)$ e três doses de boro $\left(0,5 ; 1,5 \mathrm{e} 4,5 \mathrm{mg} \mathrm{dm}^{-3}\right)$ no plantio em esquema fatorial de $3 \times 3 \times 2$, com quatro repetições. Houve diferentes comportamentos entre os porta-enxertos no que se refere à composição mineral de folhas de limoeiro 'Siciliano', bem como, no desenvolvimento do sistema radicular, sendo maior na laranjeira azeda em relação ao limoeiro cravo. Não houve nenhum efeito na interação de níveis de saturação por bases e doses de boro para nenhum dos parâmetros avaliados.

\section{REFERENCES}

Aso, P. J. (1974), Tolerância de plantines de portainjertos cítricos a vários niveles de carbonato de calcio en el suelo. Revista Industrial Agricola de Tucuman, 51 : (1), 35-6.

Boaretto, A. E.; Prochnow, L. I.; Muraoka, T.; Almeida, L. E. P. and Büll, L. T. (1991), Efeito do gesso e do calcário nas características químicas do solo, teores foliares e produtividade de limão siciliano (Citrus limon, Burm.) Paper presented at Congresso Brasileiro de Ciência do Solo, 23, Porto Alegre, Rio Grande do Sul, Brazil, 1991. pp. 321.

Bohm, W. (1979), Methods of studing root systems. Berlin, Springer-Verlag, (Ecologycal Studies, 33). $188 \mathrm{pp}$.

Gomes, F. P. (1981), Curso de estatística experimental. 9. ed. Piracicaba : ESALQ. 430 pp.

Grassi Filho, H. (1991), Níveis de cálcio e boro e suas interações, afetando o desenvolvimento do sistema radicular, a composição mineral e o vigor do limoeiro cravo [Citrus limonia, (L.), Osbeck], em condições controladas. McSc Thesis, Escola Superior de Agricultura "Luiz de Queiroz"/USP, Piracicaba, Brasil. 92 pp.
Grassi Filho, H. (1995), Adições de calcário e boro influenciando características fenológicas $e$ composição foliar do limoeiro Siciliano enxertado sobre dois porta-enxertos. $\mathrm{PhD}$ Thesis, Escola Superior de Agricultura "Luiz de Queiroz"/USP, Piracicaba, Brazil. 76 pp.

Grupo Paulista de Adubação e Calagem para Citros (1994), Recomendações de adubação e calagem para citros no Estado de São Paulo. 3. ed. Cordeirópolis. 27 pp.

Hiroce, R.; Figueiredo, J. O.; Pompeu Jr., J. and Martins, A. L. M. (1986), Infuência de 16 portaenxertos na composição mineral das folhas de limoeiro 'Siciliano', Citrus limon (L.) Burm. F. Paper presented at Congresso Brasileiro de Fruticultura, 8., Brasília, 1986. Anais... Brasília D.C. EMBRAPA/Conselho Nacional de Desenvolvimento Científico e Tecnológico. v.1. pp.161-5.

Malavolta, E. and Violante Netto, A. (1989), Nutrição mineral, calagem, gessagem e adubação dos citros. Piracicaba : Potafos. 153 pp.

Malavolta, E.; Vitti, G. C. and Oliveira, S.A. (1989), Avaliação do estado nutricional de plantas: princípios e aplicações. Piracicaba : Potafos. 208 pp.

Marschner, H. (1986), Mineral nutrition of higher plants. New York : Academic Press. 674 pp.

Mengel, K. and Kirkby, E. A. (1987), Principles of plant nutrition. 4. ed. Bern : International Potash Institute, 655p.

Montenegro, M. W. S. (1960), Contribuição ao estudo do sistema radicular das plantas cítricas. Piracicaba, (Catedra-Escola Superior de Agricultura "Luiz de Queiroz"/ USP). 143 pp.

Quaggio, J. A.; Teófilo Sobrinho, J. and Dechen, A. R. (1992), Magnesium influences on fruits yield and quality of "Valencia" sweet orange on rangpur lime. Proceedings of the International Society of Citriculture, Acireale, 2, 633-637.

Raij, B. van and Quaggio, A. J. (1983), Métodos de análise de solo para fins de fertilidade. Campinas : Instituto Agronômico. (IAC - Boletim Técnico, 81). 31 pp.

Rodrigues, O.; Inforzato. R. and Teófilo Sobrinho, J. (1978), Estudo do sistema radicular de três portaenxertos para citros em viveiro. Revista Brasileira de Fruticultura, 1 : (1), 23-30.

Schenk, M. K. and Barber, S. A. (1979), Root characteristics of corn genotypes as related to $\mathrm{P}$ uptake. Agronony Journal, 71 : (12), 921-4.

Tennant, D. (1975), A test of a modified line intersect method of estimating root lengh. Journal Ecological, 63, 995-1001.

Violante Netto, A.; Raij, B. van; Blasco, E. E. A.; Vitti, G. C.; Cantarella, H.; Teófilo Sobrinho, J.; Quaggio, J. A.; Negri, J. D.; Rodrigues, O.; Bataglia, O. C. and Malavolta, E. (1988), Recomendações de adubação e calagem para os citros no Estado de São Paulo. Cordeirópolis : Estação Experimental de Limeira. 32 pp. 
Zanette, F.and Comem, J. C. (1992), Estudo do sistema radicular das plantas. Paper presented at Reunião Brasileira de Fertilidade do Solo e Nutrição Mineral de Plantas, 20. Piracicaba. Anais... Campinas, Fundação Cargill. pp. 395-403.

Received: September 17, 2002;

Revised: August 19, 2003;

Accepted: March 10, 2004. 